\title{
Ticks of the genus Rhipicephalus Koch, 1844 in Senegal: Review host associations, chorology, and associated human and animal pathogens
}

\author{
Massamba Sylla1,2* Marc Souris $^{3}$ Jean-Paul Gonzalez ${ }^{4,5}$
}

\section{Keywords}

Rhipicephalus, hosts, vectors, pathogens, geographical distribution, environment, Senegal

Accepted: 30 October 2020

Published: 31 March 2021

DOI: $10.19182 /$ remvt.36318

\begin{abstract}
Summary
Ticks of the genus Rhipicephalus (Acari: Ixodidae) in Senegal were reviewed. The data presented originate from a tick collection maintained at IRD's Laboratory of Medical Entomology since 1967 and continuously enriched with samples obtained from different vertebrate hosts captured during various projects conducted in Senegal from 1987 to 2007. Fifteen Rhipicephalus tick species were collected and characterized, resulting in 1127 referenced collections. Three species were of the Boophilus subgenus: Rhipicephalus (Bo.) annulatus, Rh. (Bo.) decoloratus and $R h$. (Bo.) geigyi. The twelve others were Rh. boueti, Rh. cuspidatus, Rh. evertsi, Rh. guilhoni, Rh. lunulatus, Rh. muhsamae, Rh. sanguineus, Rh. senegalensis, $R h$. sulcatus, Rh. tricuspis, Rh. turanicus and Rh. ziemanni. Although there were recent indications that Rh. turanicus should have been considered as part of the Rh. sanguineus s.l. complex, data regarding these two ticks were presented separately. The collection comprised 14,165 tick specimens at different developmental stages. Data concerning their host relationships as well as distribution and seasonal dynamics were also presented. Vertebrate hosts were identified and listed in the different ecological zones of Senegal. The role of the ticks as potential vectors of pathogens has been reviewed. Climate change, causing variations in rainfall and temperature, will impact tick distribution and dynamics. The situation supports the necessity of this inventory of tick populations for (re)emerging tick-borne diseases surveillance and monitoring.
\end{abstract}

- How to quote this article: Sylla M., Souris M., Gonzalez J.-P., 2021. Ticks of the genus Rhipicephalus Koch, 1844 in Senegal: Review host associations, chorology, and associated human and animal pathogens Rev. Elev. Med. Vet. Pays Trop., 74 (1): 61-69, doi: 10.19182/remvt.36318

\section{INTRODUCTION}

Since the beginning of the 1970s, a drought cycle without equivalent elsewhere in the world persists in sub-Saharan Africa. Compared to 1947-1968, the average annual rainfall actually decreased by $200 \mathrm{~mm}$,

1. UR 178, Conditions et territoires d'émergence des maladies (CTEM), Institut de recherches pour le développement (IRD), Centre IRD de Hann, BP 1386, CP 18 524, Dakar, Sénégal.

2. Laboratoire Vecteurs \& Parasites, Département sciences et techniques de l'élevage, Université du Sine Saloum El Hadji Ibrahima NIASS (USSEIN), Campus de Kaffrine, Sénégal.

3. UR 178 CTEM, IRD, UMR Unité des virus émergents, Marseille, France.

4. UR 178 CTEM, IRD, Montpellier, France.

5. Georgetown University, School of Medicine, Washington, DC, USA.

* Corresponding author

Tel.: +221 3384935 35; Email: massylla19@gmail.com corresponding to a deficit of 20\% to 50\% (L'Hôte and Mahé, 1996; Le Barbé et al., 2002). Since the World Meteorological Organization began recording average temperatures on Earth in 1860, the United States of America's National Aeronautics and Space Administration (www.giss.nasa.gov/research/news/20190206/) recorded the highest temperatures on the surface of the Earth from 2015 to 2019, showing a continuum in the Planet's long-term warming trend. The five warmest years are all posterior to 2010, year 2016 recording the highest globally averaged land surface temperature at $2.35^{\circ} \mathrm{C}$ above the 20th century average (NOAA, 2017). Dry years have become more frequent, occur at shorter intervals (Kasei et al., 2010), and the areal coverage of drought has also increased in Western Africa. More severe future droughts are predicted in the Sahel (Shanahan et al., 2009). Climate change projections in sub-Saharan Africa point to a warming trend, with frequent occurrences of extreme heat events, increasing aridity and changes in rainfall patterns (Serdeczny et al., 2016).

Several emerging and reemerging infectious diseases, related to climatic changes have suddenly appeared in naïve animal and human 
populations in Africa in the last decades, and several works were undertaken to tackle particularly those that were vector-borne. Temperature changes as well as rainfall intensity and variability are assumed to have marked effects on the vectorial capacity of arthropod vectors of viral, bacterial and parasitic diseases (Kovats et al., 2001; Patz et al., 2008). The understanding of the current chorology of ticks, especially those known as vectors of pathogenic agents, appears crucial in view of climatic changes (i.e. temperature, hygrometry), which underlie their current and future distribution and the risk of emergence of their carried pathogenic agents. In this context, we intended to review rhipicephalid ticks known in Senegal for future follow-up studies on tick-borne diseases.

The genus Rhipicephalus Koch, 1844 (Ixodidae, Rhipicephalinae), is the richest of the ixodid fauna of the Western subregion of the Afrotropical zoogeographical region (referred to hereafter as the Western subregion) (Camicas et al., 1998; Walker et al., 2000; Morel, 2003). Most of its members parasitize mammals in the African continent. Except for the newly defined subgenus Boophilus (Beati and Keirans, 2001; Murrell and Barker, 2003) which is monophasic, and Rhipicephalus evertsi, a two-host exophilic tick, Rhipicephalus spp. have a three-host life cycle mostly associated with wild animals but they also possibly infest livestock. Recently, Rh.turanicus, which was until now considered as a separate taxon, was synonymized with Rh. sanguineus (Nava et al., 2015; Hekimoğlu et al., 2016). The data concerning both species are however presented separately below. To establish a list of the ixodid fauna infesting livestock and wild animals in Senegal, various studies have been carried out (Sylla et al., 2007; Sylla et al., 2008a). The present review lists the Rhipicephalus species occurring in Senegal, and reports their host association, chorology, and disease relationships.

\section{MATERIALS AND METHODS}

The research complied with legal requirements of the Senegalese authorities and adhered to the principles for the ethical treatment of wildlife. An authorization to conduct wild animals trapping and tick collections was granted by the Direction of Wildlife Services, Ministry of Environment and Nature Protection, Senegal (Approval \# 001270 DEF/DGF 2002, Direction des eaux et forêts, chasses, et de la conservation des sols), and ratified by the Research Institute for Development (IRD, Marseille, France).

The data presented here originate from a tick collection currently held at IRD Laboratory of Medical Zoology, at Mbour Center, 90 kilometers southeast of Dakar (Senegal). This collection, set up in the 1960s, has been continuously enriched over time by different tick research projects conducted in Senegal. The Crimean-Congo Hemorrhagic Fever (CCHF) Program, 1987-1993, aimed to identify the tick species involved in CCHF virus ecology in the birds, wild mammals and livestock investigated, after ticks were removed for virus detection (Camicas et al., 1990). The climatic Change and Health Project (IRD, Action thématique interdisciplinaire, 2003-2004) focused on tick inventory and the impact of climatic change on their geographical distribution with respect to CCHF risk of emergence in Senegal and Mauritania (Wilson et al., 1990). During these two studies, rodents have also been caught in different geographical areas of Senegal and ticks removed and conserved for further studies. Ultimately, the EDEN project (European Commission, 2004-2007) related to West Nile virus ecology led to bird trapping in the 'Parc national des oiseaux du Djoudj' and the settlement of Barkedji where ticks were removed for virus research. Study sites and tick sampling have been presented in detail elsewhere (Sylla et al., 2007; 2008a).

Geographical position of each locality where a tick sample was found was given either by the gazetteer of Senegal (Board on Geographic
Names, 1965, Dpt. of the Interior, Washington, DC, 20240, 1965, IV + 194 p.) or using GPSMAP 62S (Garmin, Wichita, Kansas). Maps were generated with SavGIS software (IRD, www.savgis.org). A sample (or a collection) is the total tick species (larval, nymphal and adult stages) removed from a vertebrate host in a given location, at the same date. Different tick species can be found simultaneously infesting the same vertebrate host. Rhipicephalus spp. were identified with the available identification key adapted to the ixodid fauna of the Western subregion (Matthysse and Colbo, 1987; Walker et al., 2000), and following the systematic terminology retained in Morel (2003), species nomenclature updated by Guglielmone et al. (2010), Nava et al. (2015), and Hekimoğlu et al. (2016). Mammal hosts identification followed Nowak (1999), and Wilson and Reeder (1992) with subsequent minor changes concerning some species, whereas bird host identification was carried out according to Del Hoyo et al. (1994).

\section{RESULTS}

\section{Tick species identified}

Of the 14,165 specimens collected parasitizing mammals and birds, 15 Rhipicephalus species were identified (table I). They included three species of the subgenus Boophilus Curtice, 1891 (Murrell and Barker, 2003), Rh. (Boophilus) annulatus, Rh. (Bo.) decoloratus and Rh. (Bo.) geigyi.

Until recently, other subgenera were considered in the Rhipicephalus genus. Rh.evertsi belonged thus to the subgenus Digineus Pomerantsev, 1936, and Rh. cuspidatus to the subgenus Hyperaspidion Pomerantsev, 1936. Both species are now classified as Rhipicephalus (Guglielmone et al., 2010), as are the other identified species: $R h$. lunulatus, $R h$. muhsamae and $R h$. senegalensis of the simus group; Rh. boueti, Rh. guilhoni, Rh. sanguineus, Rh. sulcatus, Rh.tricuspis,

Table I: Number of collections of Rhipicephalus spp. recorded and of ticks obtained per species in Senegal /// Nombre de collections de Rhipicephalus spp. répertoriées et de tiques obtenues par espèce au Sénégal

\begin{tabular}{lrr} 
Tick species & $\begin{array}{c}\text { Number of } \\
\text { collections }\end{array}$ & $\begin{array}{c}\text { Total ticks } \\
\text { collected / species }\end{array}$ \\
\hline Rh. (Boophilus) annulatus* & 0 & 0 \\
Rh. (Boophilus) decoloratus & 127 & 2,368 \\
Rh. (Boophilus) geigyi & 74 & 1,721 \\
Total Rh. (Boophilus) & 201 & 4,089 \\
Rh. evertsi & 196 & 2,610 \\
Rh. cuspidatus & 31 & 533 \\
Rh. boueti & 1 & 3 \\
Rh. guilhoni & 133 & 1,329 \\
Rh. lunulatus & 17 & 121 \\
Rh. muhsamae & 147 & 2,148 \\
Rh. sanguineus & 35 & 220 \\
Rh. senegalensis & 49 & 1,014 \\
Rh. sulcatus & 308 & 2,025 \\
Rh. tricuspis & 1 & 4 \\
Rh. turanicus & 3 & 64 \\
Rh. ziemanni & 5 & 5 \\
Other Rhipicephalus & 926 & 10,076 \\
Overall total & 1,127 & 14,165
\end{tabular}

* This species has been recorded in Senegal (Morel, 1958) but specimens did not exist in the collection /// Cette espèce a été répertoriée au Sénégal (Morel, 1958) mais les spécimens n'existaient pas dans la collection 
$R h$. turanicus (now synonymized with $R h$. sanguineus) and $R h$. ziemanni of the sanguineus group.

Two main groups were actually distinguished in the former subgenus Rhipicephalus, the sanguineus and simus groups (Camicas et al., 1998), defined on the basis of morphological and bioecological features. This separation does not appear in the recent list of species (Guglielmone et al., 2010; Nava et al., 2015) but we kept it because we consider it as helpful.

The sanguineus group is featured by small to medium sized interstitial punctuations, sparsely distributed through the scutum (density of these punctuations is highly variable, sometimes very dense). Posteromedian stripes (or posterior grooves) appear distinct (deep and wide with wrinkled texture). Seven species of this group are known in Senegal, but also in the Western subregion: Rh. boueti, Rh. guilhoni, Rh. sanguineus, Rh. sulcatus, Rh.turanicus, Rh. tricuspis and Rh. ziemanni.

The simus group is characterized by a smooth scutum with few scattered medium sized punctuations, the scapular field a little bit raised, smooth and flat. Posteromedian stripes or posterior grooves appear as lines. Three species belonging to this group are known in Senegal and the Western subregion: Rh. lunulatus, Rh. muhsamae, and $R h$. senegalensis.

\section{Rhipicephalus (Boophilus) annulatus (Say, 1821) Salmon \& Stiles, 1901}

Morel (1958; 2003) reported Rh. (Bo.) annulatus infesting cattle in 1956 and 1963 in two locations of Southern Senegal. He stated that this species was present on ruminants in Senegal in the Sudanese and North-Guinean areas. Our investigations did not allow to find it, although it is recorded in Guinea and Mali (Tomassone et al., 2004). The occurrence of this species in South Senegal (Lower Casamance and Eastern Senegal) might be affected by the rainfall decline (2000$2500 \mathrm{~mm}$ annual rainfall in $1958 \mathrm{vs} 1000-1200 \mathrm{~mm}$ in the $1980 \mathrm{~s}$; L'Hôte and Mahé, 1996).

\section{Rhipicephalus (Boophilus) decoloratus (Koch, 1844) Stiles \& Hassall, 1901}

The 'African blue tick' has been frequently recorded (Figure 1) from livestock, mainly cattle, but also goats, sheep and donkeys, and accidentally from one human (Suppl. Mat. I). The species was not collected from wild animals. Rh. (Bo.) decoloratus was recorded mainly in the Sahelian and Sudano-Sahelian zones, but occasionally in the Sudanese zone (Figure 1), confirming previous observations indicating that it infests the four-fifths of the northern parts of the country (Camicas et al., 1986). In the Sahelian area, it is present along the Senegal River Basin (north of the country) and in the Niayes (Northwestern coastal region with dunes and depressions favorable for gardening), but also in the Ferlo (central and western parts of the Sahelian area). In the Niayes, the species is present on cattle all year round (rare from April to June, abundant from July through January, decreasing in population from February to March).

\section{Rhipicephalus (Boophilus) geigyi Aeschlimann \& Morel, 1965}

Known only in the meridional part of Senegal, south of isohyet $1000 \mathrm{~mm}$ (Morel, 2003), and therefore characteristic of the Sudanese and Sudano-Guinean areas, Rh.(Bo.) geigyi is a parasite of wild and domestic ungulates, mainly cattle, in Senegal (Figure 1, Suppl. Mat. II). Adults of the species were also recorded in 1960-1963 in the Niayes on cattle present all year round. It was probably introduced during importation of cows from Tambacounda and Kedougou (Southeast), Kolda and Casamance (Southwestern regions), for the purpose of research on rinderpest (Camicas, pers. commun.). Although located between latitudes $14^{\circ} 30^{\prime}$ and $16^{\circ} \mathrm{N}$, the Niayes belong to a particular ecosystem of the Sahelian zone. The relief is characterized by dune strips alternating with interdune depressions (or bowls) where a large variety of vegetable and fruit crops are grown, in an atypical vegetation of sub-Guinean chorological affinity dominated by Elaeis guineensis, that refer to lower Casamance. The continental front of the shoreline allows a global view of depressions flooded during heavy rains. This area is nevertheless characterized by a tropical sub-Canarian climate that could settle durably Rh. (Bo.) geigyi in this microhabitat of the Niayes. Nevertheless, the most recent exhaustive study in the area did not record the species occurrence (Gueye et al., 1986). More investigations are thus needed.

\section{Rhipicephalus evertsi Neumann, 1897 sensu Dönitz, 1910}

The red-legged $R$ h. evertsi tick is a monotropic exophilic species, very common and with a large distribution throughout Africa, especially in warmer areas, preferentially active during the summer. It is mainly found on all ungulates of its natural distribution area (Figure 2,

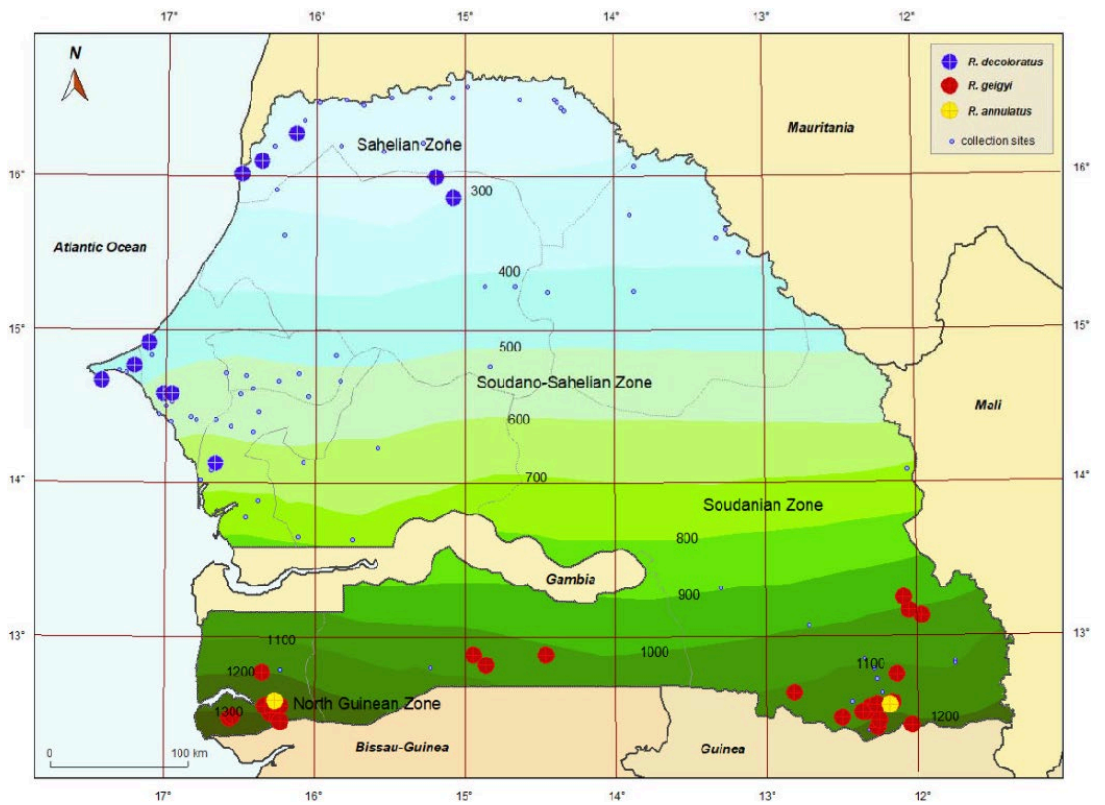

Figure 1: Distribution of tick collections carried out in Senegal in which Rhipicephalus (Boophilus) was identified /// Répartition des collectes de tiques effectuées au Sénégal dans lesquelles Rhipicephalus (Boophilus) a été identifié 
Suppl. Mat. III). On the other hand, Rh. evertsi is not frequent on carnivores, primates and leporids. It is a two-host tick, i.e. larvae and nymphs feed on the same host, where larva metamorphosis occurs. In Senegal, it was collected from domestic ruminants as well as from horses and donkeys, from the north of the country to the limit of the Sudanese zone corresponding to isohyet $800 \mathrm{~mm}$ (except only for one collection).

\section{Rhipicephalus cuspidatus Neumann, 1906}

$R h$. cuspidatus three-host species, observed from Senegal to Sudan, is typically endophilous and associated with some wild mammals and their sheltering habitats: the aardvark or antbear (Orycteropus afer), the common warthog (Phacochoerus africanus) and the African-crested porcupine (Hystrix cristata). It is also sometimes found exophilic from Sahelian savanna to Guinean woodlands where it may infest sheep and goats as well as several carnivores as the caracal (Felis caracal), the African civet (Civettictis civetta) and the blacktailed mongoose or common slender mongoose (Galerella sanguinea, also known as Herpestes sanguineus) (Figure 3, Suppl. Mat. IV).

\section{Rhipicephalus boueti Morel, 1957}

Three males of the small reddish-brown Rh. boueti tick were collected from a rock hyrax (Procavia capensis) in Southeastern Senegal (Figure 4). This species has been described by Morel (1957), but it is only known in its adult stages parasitizing the hyrax and was initially collected in Benin. Immature stages of this rhipicephalid are thus not yet known neither are data concerning its life cycle.

\section{Rhipicephalus guilhoni Morel \& Vassiliades, 1963}

Immature stages of Rh. guilhoni (Morel and Vassiliades, 1964) are known from myomorph and sciuromorph rodents, whereas adults infest a large variety of ungulates, carnivores, leporids and sometimes birds. Adult $R h$. guilhoni frequently parasitizes livestock in the northern half of Senegal and is mostly found at isohyets $250-500 \mathrm{~mm}$ (Figure 4, Supp. Mat. V). It has been currently recorded from cattle of different origins at Dakar's slaughterhouses. It has been found parasitizing diverse wild animals including the barn owl (Tyto alba affinis), the African hedgehog (Atelerix albiventris), the serval (Felis serval), the African wildcat (Felis lybica) and the zorilla or striped polecat



Figure 2: Distribution of tick collections carried out in Senegal in which Rhipicephalus evertsi was identified /// Répartition des collectes de tiques effectuées au Sénégal dans lesquelles Rhipicephalus evertsi a été identifié

Figure 3: Distribution of tick collections carried out in Senegal in which Rhipicephalus cuspidatus was identified /// Répartition des collectes de tiques effectuées au Sénégal dans lesquelles Rhipicephalus cuspidatus a été identifié

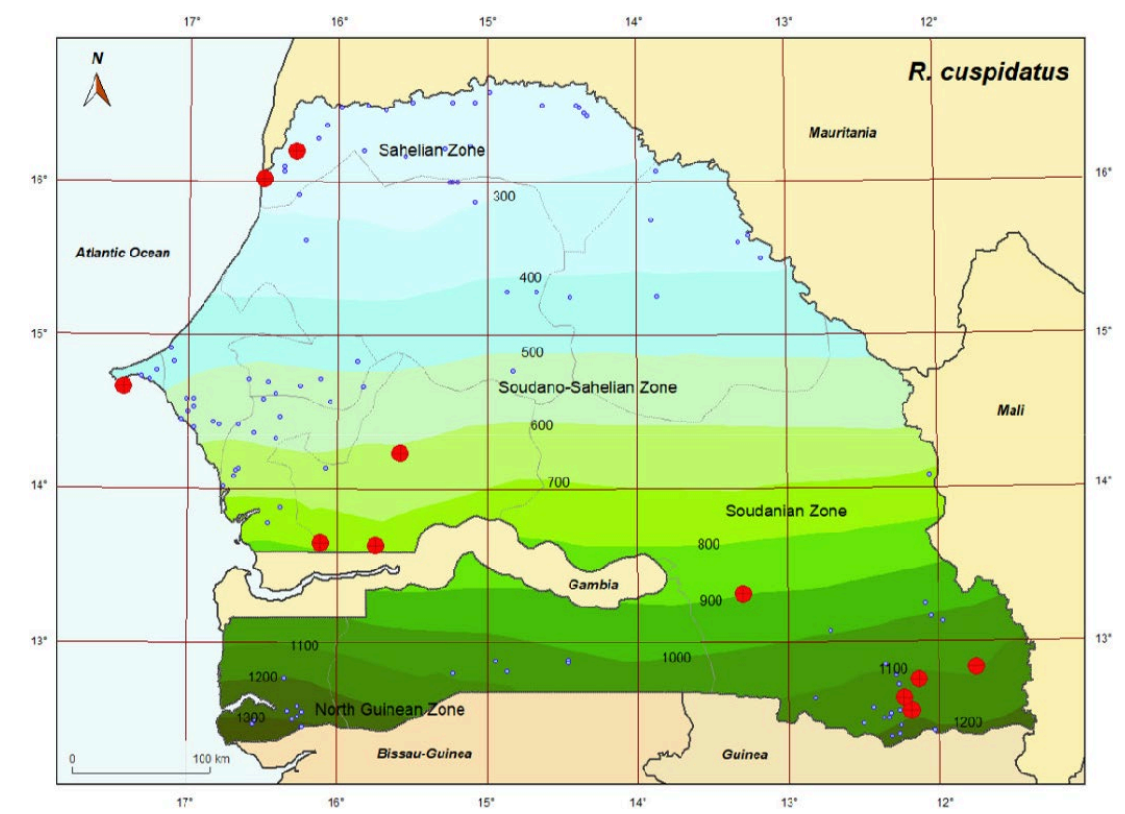




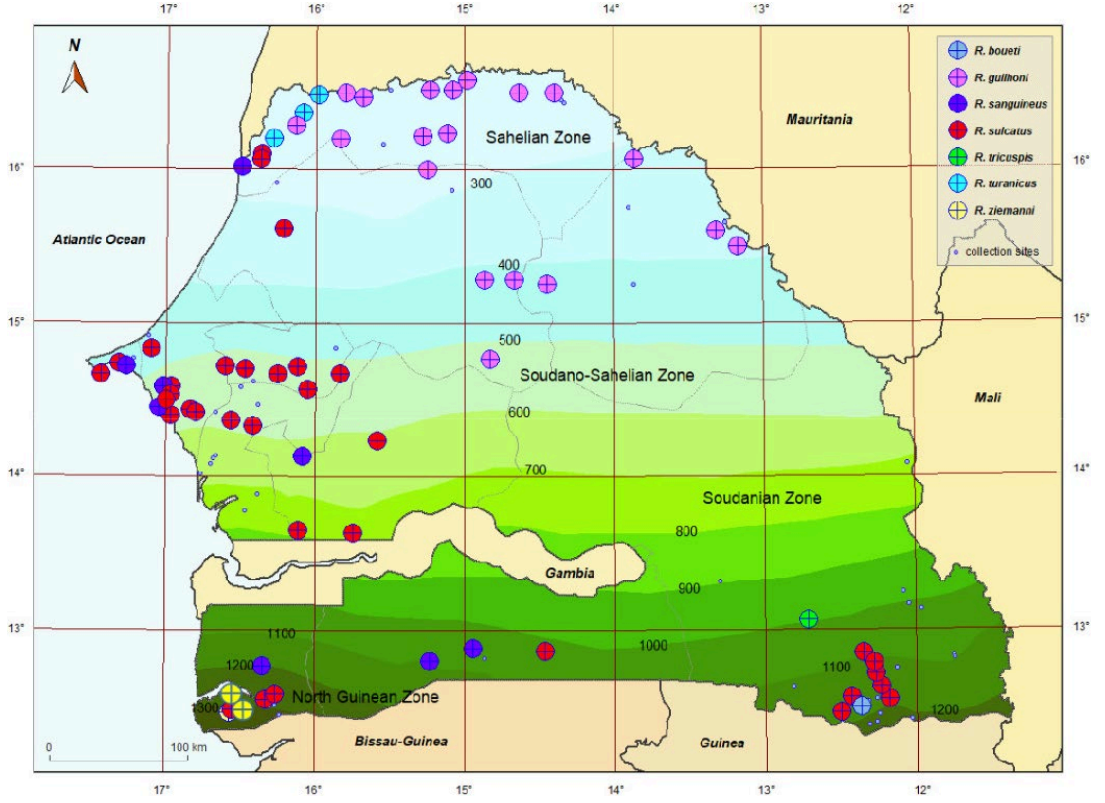

Figure 4: Distribution of tick collections carried out in Senegal in which Rhipicephalus of the group sanguineus was identified /// Répartition des collectes de tiques effectuées au Sénégal dans lesquelles Rhipicephalus du groupe sanguineus a été identifié
(Ictonyx striatus). It was also collected from humans or crawling on the ground. In Senegal, 133 mammals were found infested, three more collections were obtained from birds (data not shown), and the tick was also collected in natura on four occasions (96 adults, sex ratio at equilibrium).

\section{Rhipicephalus sanguineus (Latreille, 1806) Koch, 1844}

Also known as the kennel tick, brown dog tick or pantropical dog tick, adult $R h$. sanguineus infests a large variety of ungulates including livestock and wild carnivores in diverse ecological areas of Senegal (Figure 4, Suppl. Mat. VI). Morphological features within the species allowed to delineate some individuals but recent findings based on laboratory crosses and molecular genetics changed the taxonomic status of the sanguineus group (Nava et al., 2015). This tick is very common on the domestic dog (Canis lupus familiaris). Other collections held in the laboratory (data not shown) recorded it also from $I$. striatus, the pale fox (Vulpes pallida), the Senegal bushbaby (Galago senegalensis) and from the black kite (Milvus migrans). On ten occasions, it was collected in natura, questing or crawling to find a host,

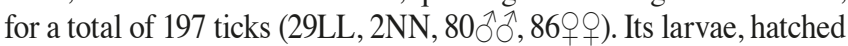
from eggs probably laid by females fed on domestic dogs, have been noticed invading homes in several localities of Senegal.

\section{Rhipicephalus sulcatus Neumann, 1908}

Immature stages of $R h$. sulcatus are known to parasitize mainly hedgehogs, and myomorph and sciuromorph rodents, whereas adults infest a large variety of ungulates, carnivores, leporids, hedgehogs (Figure 4; Suppl. Mat. VII), and sometimes birds and reptiles. This adult species is common on livestock from north to south Senegal, but absent in the Ferlo (Figure 4). It was collected from 308 mammals, 5 birds, and 1 reptile, the Nile monitor (Varanus niloticus). In addition, 12 collections making a total of 56 ticks $(36 \hat{\jmath} \widehat{\jmath}, 20 q$ + $)$, were obtained in natura, questing or crawling to find a host.

\section{Rhipicephalus tricuspis Dönitz, 1906}

Rh. tricuspis was collected only once, from a harnessed bushbuck (Tragelaphus scriptus) infested by four male ticks, in Niokolo-Koba National Park (Morel, 1956) (Figure 4). It has the simus pattern punctuations on the central conscutum and might therefore be confused with Rh. lunulatus (Morel, 2003). It is a typical parasite of domestic animals and it is sometimes collected on small wild carnivores, antelopes and spring hares in South Africa, in the Austral biogeographic subregion. As in the case of $R h$. boueti, little is known in Senegal about its immature stages morphology and/or bioecology.

\section{Rhipicephalus turanicus Pomerantsev et al., 1940}

Synonymized with $R h$. sanguineus, immature stages of $R h$. turanicus are known to infest myomorph and sciuromorph rodents, and wild and domestic carnivores. This species is rarely collected in Senegal (Table I; Figure 4). It is very localized and recorded only from goats in Northern Senegal. Pegram et al. (1987) listed some specimens from Senegal without giving the collection sites. Camicas (pers. commun.) stated that specimens identified as Rh. guilhoni in Main et al. (1980) were in fact a mix of $R h$.guilhoni and Rh.turanicus.

\section{Rhipicephalus ziemanni Neumann, 1904 emend. Neumann, 1911}

Rh. ziemanni is found on goats and sheep pasturing in periforested areas (Figure 4) because it mainly infests wild antelopes in the forest. It has also been occasionally recovered from Bos taurus. Villiers (1955) recorded it from Tragelaphus scriptus $\left(1{ }^{1}\right)$, and Civettictis civetta $\left(1 \hat{O}^{\Uparrow}\right)$ in Southwest Senegal. As is the case for Rh. boueti and Rh. tricuspis, little is known about its immature stages, morphology and/or bioecology. Its seasonality and geographical distribution in Senegal need to be elucidated.

\section{Rhipicephalus lunulatus Neumann, 1907}

Rh. lunulatus is triphasic and ditropic. Adults infest a large variety of ungulates (Suppl. Mat. VIII) and carnivores but are also frequently found on Leporidae and antbears. This species has been recovered in the Sudano-Sahelian zone and the Sudanese area, south of isohyet $750 \mathrm{~mm}$, in the natural region of Casamance (Figure 5). Besides the collections from hosts, $10^{1}$ was collected on the ground.

\section{Rhipicephalus muhsamae Morel \& Vassiliades, 1963}

Immature stages of three-host Rh. muhsamae (Morel and Vassiliades, 1964) are known to infest myomorph and sciuromorph rodents and leporids, whereas adults infest a large variety of ungulates and carnivores. It is distributed from north to south Senegal, in the Niayes and the Northern Sahelian area, along the Senegal River, but it is also frequent at isohyets $750-1000 \mathrm{~mm}$ in the southeastern and southwestern parts of Senegal (Figure 5). The species infests hedgehogs and birds and is frequently found as adults on livestock (Suppl. Mat. IX). Adults can also parasitize primates, antbears and African porcupines. It is found on cattle preferentially feeding on the ears 


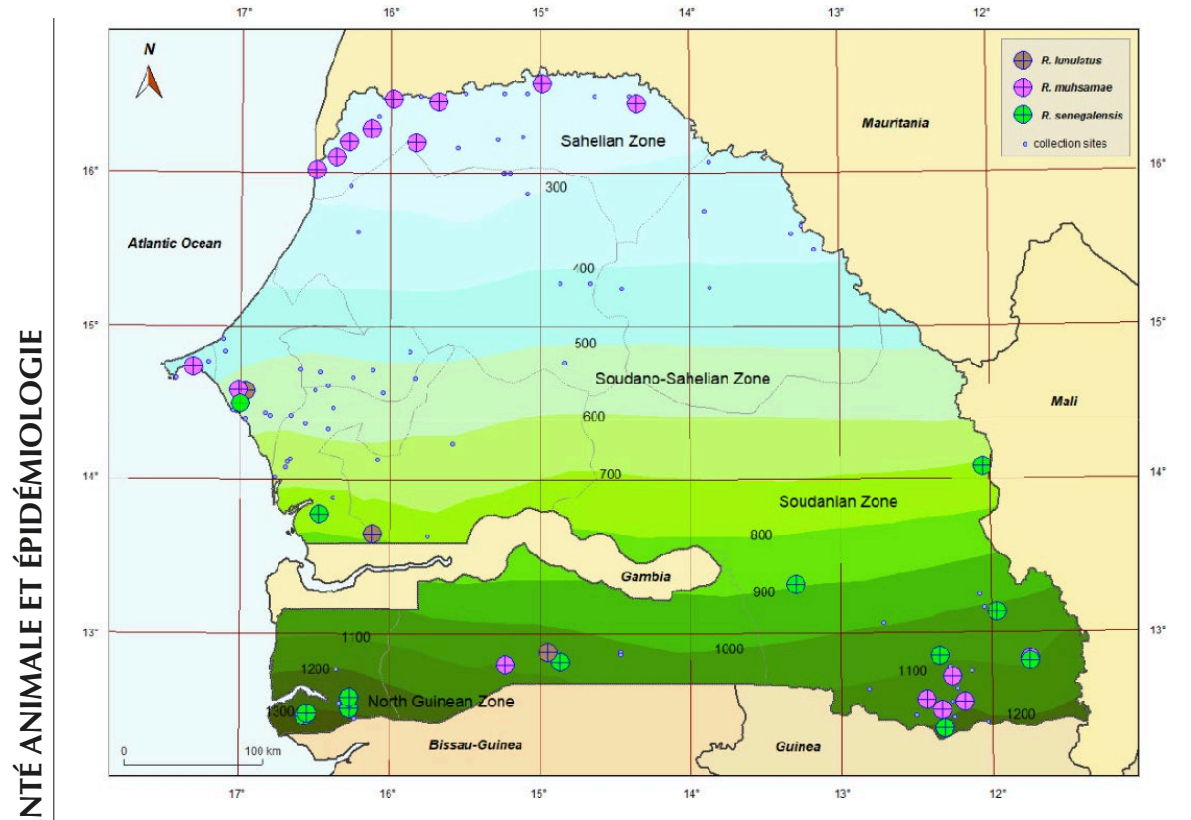

Figure 5: Distribution of tick collections carried out in Senegal in which Rhipicephalus of the group simus was identified /// Répartition des collectes de tiques effectuées au Sénégal dans lesquelles Rhipicephalus du groupe simus a été identifié (observations recorded all year long from November 1960 through November 1963) with maximum infestation in July. It has also been identified on rodents of the family Muridae (Taterillus sp. or gerbils). Eleven collections of Rh. muhsamae making a total of 22 ticks ( $13 \hat{\partial} \delta^{\lambda}$, $9+$ ) ) were also obtained in natura, questing or crawling to find a host.

\section{Rhipicephalus senegalensis Koch, 1844}

Immature stages of Rh. senegalensis infest myomorph and sciuromorph rodents, whereas adults are found on all ungulates and carnivores restricted to the species natural distribution areas, overlapping the humid parts of Senegal (Figure 5, Suppl. Mat. X), where it shares the same occurrence areas with Rh. muhsamae. However, Rh. senegalensis is also exceptionally found in North Senegal, around humid zones such as the irrigated lands of Walo (Sahelian zone), around Bao Bolon (Nioro du Rip, Sudano-Sahelian zone). Other records of $R h$. senegalensis in Senegal are from Villiers (1955) in the National Park of Madeleine Islands near Dakar. In addition, $25 \hat{\jmath}$ and $15 \bigcirc R h$. senegalensis were collected in natura, crawling to find a host, in different sites of the species natural areas of occurrence.

\section{Carried pathogens identified:}

\section{(A) viruses, (B) bacteria and protozoa}

\section{Rhipicephalus (Boophilus) annulatus}

A: No arbovirus has been isolated from Rh. (Bo.) annulatus in Senegal so far. However, this species, known as the cattle fever tick, has been found infected with the following viruses: Bhanja in Guinea, Jos in Central African Republic (CAR), Thogoto in Cameroun and CAR (Sureau et al., 1976; Degallier et al., 1985) and Dugbe in CAR (Degallier et al., 1985).

B: The tick was found infected by the rickettsia Coxiella burnetii in Senegal (Mediannikov et al., 2010). It is also known to transmit Babesia bigemina, B. bovis and Anaplasma marginale (Bock et al., 2004; Kocan et al., 2010).

\section{Rhipicephalus (Boophilus) decoloratus}

A: The African blue tick has been found infected with Bhanja virus in Senegal (CRORA, 1998), but also in Cameroon (Vinograd et al., 1975) and Nigeria (Williams et al., 1972). CCHF virus has been also isolated from the tick in Senegal (Le Gonidec, 1975), in Nigeria
(Williams et al., 1972) and in Democratic Republic of Congo (DRC) (Degallier et al., 1985), which does not imply that the tick may be a competent vector, although CCHF virus successfully replicates in $R h$. decoloratus cell lines (Bell-Sakyi et al., 2012). The tick was also found infected with Dugbe virus in Nigeria (Williams et al., 1972) and in DRC (Sureau et al., 1976), with Jos virus in Senegal (Le Gonidec, 1975) and in Nigeria (Lee et al., 1974), and with Somone virus in Nigeria (Robin et al., 1978). Thogoto virus was also isolated from the species in Senegal (CRORA, 1998), Cameroon (Sureau et al., 1976), Kenya (Haig et al., 1965), Nigeria (Williams et al., 1972) and CAR (Sureau et al., 1976).

$\mathrm{B}$ : The tick is involved in the transmission of bovine piroplasmosis caused by Babesia bigemina. It is the vector of Anaplasma marginale, the causal agent of bovine anaplasmosis, and was also found infected with Coxiella burnetii in Senegal (Mediannikov et al., 2010).

\section{Rhipicephalus (Boophilus) geigyi}

A: Rh. (Bo.) geigyi has been found in Senegal infected with CCHF virus (Camicas et al., 1986). Elsewhere in West Africa, it was found infected with Dugbe virus in Ivory Coast, and with Jos and Forecariah (= ArK 4927) viruses in Guinea (CRORA, 1998).

\section{Rhipicephalus evertsi}

A: Rh.evertsi allows the replication of CCHF virus in the Sahelian area of Senegal. It plays a major role because all stages of the tick feed on ruminants, which are the main vertebrate hosts of the virus (Camicas et al., 1994). It has also been found infected in Senegal (CRORA, 1998) with Saboya, Wad Medani, var Wad Medani (ArD 46672) (Main et al., 1980) where Ngoye virus was also isolated from it (Grard et al., 2006), and Ndelle and Somone viruses. Amplified West Nile virus gene sequences showed significant identity from pools of the same tick species also collected from cattle in Ngoye, Senegal (Sylla and Gonzalez, unpubl. data).

B: The tick was found infected with Coxiella burnetii in Senegal (Mediannikov et al., 2010). It also transmits Anaplasma marginale (Potgieter, 1979), and Babesia equi and B. caballi (De Waal et al., 1987).

It is one of the species known to cause paralysis of the vertebrate hosts because of chemical substances secreted by ticks while feeding (Sonenshine, 1992). 


\section{Rhipicephalus guilhoni}

A: Rh. guilhoni was found infected with CCHF, Dugbe, Jos, Koutango, Semliki Forest viruses (CRORA, 1998), and Wad Medani in Senegal (Main et al., 1980).

B: The tick was also found infected with Coxiella burnetii in Senegal (Mediannikov et al., 2010).

\section{Rhipicephalus sanguineus}

A: Rh. sanguineus has not been known so far to be involved in arbovirus transmission in Senegal.

B: The tick is the vector of Ehrlichia canis, the bacteria causing canine ehrlichiosis in dogs (Fourie et al., 2013). It also transmits Rickettsia conorii causing Mediterranean spotted fever (= boutonneuse fever) to humans in the Mediterranean (Spain, Italy, Greece, France, and Portugal) where it is considered to be the main vector and reservoir of the Ri. conorii complex (Bacellar et al., 1999; Parola and Raoult, 2001; Parola et al., 2005), although in sub-Saharan Africa, $R h$. simus is the main vector. $R h$. sanguineus transmits the protozoans Babesia canis and B. gibsoni to dogs, causing canine babesiosis. The protozoan Hepatozoon canis is also transmitted from this tick to dog (Zhou et al., 2016). Finally, Borrelia burgdorferi, the etiological agent of Lyme disease, has also been detected at a lower incidence in $R h$. sanguineus ticks collected in Texas, USA (Cohen et al., 1990).

\section{Rhipicephalus sulcatus}

A: Rh. sulcatus was found infected with Dugbe virus in Senegal (CRORA, 1998; Robin et al., 1978).

\section{Rhipicephalus muhsamae}

A: Rh. muhsamae was found infected with Dugbe, Koutango, Wesselsbron and West Nile viruses in CAR (CRORA, 1998). Surveillance needs to include this species in Senegal.

\section{Rhipicephalus cuspidatus and Rhipicephalus lunulatus}

To our knowledge, there is no information on Rh. cuspidatus and $R h$. lunulatus potential to replicate and transmit pathogens to humans or animals.

\section{Rhipicephalus senegalensis}

B: Rh. senegalensis was found carrying Rickettsia massiliae, Ri. aeschlimannii and Ri. africae among others yet not determined (Reye et al., 2012; Ehounoud et al., 2016).

\section{Rhipicephalus boueti and Rhipicephalus ziemanni}

Little is known about the potential of these species of the simus group to carry pathogens.

\section{DISCUSSION}

Further research extended to Sudanese and Sudano-Guinean zones are needed to determine $R h$. (Bo.) annulatus occurrence/repartition in Senegal. The relations between the $R h$. (Bo.) species occurring in Senegal and CCHF virus ecology need also to be studied. From a medical and veterinary point of view these species have been underestimated, few studies having been conducted in Senegal. Nevertheless, because of the monotropic and monophasic characters of $R h$. (Bo.) species, they might play a major role in CCHF virus ecology only in case of transovarian transmission of the virus. Throughout South Senegal, prospections need to be carried out on Rh. decoloratus distribution to clarify its absence/presence in the natural region of Casamance and Eastern Senegal, where it is supposed to be replaced by Rh. geigyi. Indeed, Rh. geigyi's ability to transmit Babesia sp. and CCHF virus needs to be evaluated. Rh. (Bo.) species are the main vectors of B. bigemina and B. bovis causing babesiosis (or piroplasmosis) in livestock.

Following phylogenetic studies (Beati and Keirans, 2001; Murrell and Barker, 2003), the names of the Boophilus ticks changed and became Rhipicephalus of the subgenus Boophilus. Rh. (Boophilus) are small sized ticks that share the same generally hexagonal basis capituli with the other Rhipicephalus ticks. However, Rhipicephalus spp. are featured by medium sized males, a distinct anal groove, the presence of festoons, spiracular plates with a tail, whereas Rh. (Boophilus) are characterized by an indistinct anal groove, the absence of festoons and oval or rounded spiracular plates. Their palpi are very short, and males are small sized. Rh. (Boophilus) spp. occur in the tropical and subtropical areas, and preferentially feed on livestock. They are monophasic: the three developmental stages evolve on the same host; hatched larvae seeking host and engorged females are therefore the only free stages; metamorphosis from larva to nymph and nymph to imago takes place on the host. These bioecological features differ from those of the other Rhipicephalus spp. which are diphasic $(R h$. evertsi) or triphasic. For the latter, three hosts are parasitized during the life cycle, the host specificity varies between tick species and molting occurs off the host.

We already have shown tick species that changed their distribution range in Northern Senegal, creating new CCHF foci following the sub-Saharan drought of the 1970s (Sylla et al., 2008a; 2008b). Globally, climate change effects on epidemiological dynamics such as vector and host migration are not well known because of the unavailability of valid retrospective ecological data on reservoirs and vectors. Evolution in chorology, host association database, and known transmitted pathogens become informative, correlated to ecoclimatic events. Several reasons linked to diversity of implicated phenomena and spatiotemporal scales are to be considered. In the developing countries of the intertropical belt, particularly in Africa, bioclimatic features support a strong epidemiological potential for numerous infectious diseases, as soon as ecological changes arise. Modest changes of some climatic parameters induce epidemiological phenomena of high amplitude. Frequent and long-term sampling are needed to monitor the full range of specific vector species (Kovatz et al., 2001) in order to understand the epidemiological patterns involved in the emergence and spread of diseases in a changing environment, to predict risk, and set up early warning and control strategies.

\section{Acknowledgments}

This work was supported by the « Action thématique interdépartementale, évolution climatique et santé 2003-2004 »(ATI), Institut de recherche pour le développement (IRD), EDEN Project (European Commission funding, 2004-2007), unités de recherche 34/178, Sociétés et santé, IRD, Crimean-Congo Haemorrhagic Fever Program, CCHF1987-1993. We thank the anonymous reviewers and the editorial staff of Revue d'élevage et de médecine vétérinaire des pays tropicaux for their invaluable contribution. We also would like to thank the farmers from Senegal who allowed us to collect ticks. This work is dedicated to the late Dr. Jean-Louis Camicas for his constant support, his generous gift of records of some specimens, and his review of the earlier version of the manuscript.

\section{Author contributions statement}

MSy carried out field collections and tick identification; MSy, MSo and JPG conceived the project and wrote the manuscript.

\section{Conflicts of interests}

The authors declare no competing interests. 


\section{REFERENCES}

Bacellar F., Beati L., França A., Poças J., Regnery R., Filipe A., 1999. Israel spotted fever Rickettsia (Rickettsia conorii Complex) associated with human disease in Portugal. Emerg. Infect. Dis., 5 (6): 835-836, doi: 10.3201/ eid0506.990620

Beati L., Keirans J.E., 2001. Analysis of the systematic relationships among ticks of the genera Rhipicephalus and Boophilus (Acari: Ixodidae) based on mitochondrial $12 \mathrm{~S}$ ribosomal DNA gene sequences and morphological characters. J. Parasitol. 87 (1): 32-48, doi: 10.1645/0022-3395(2001)087[0032:AOTSRA]2.0.CO;2

Bell-Sakyi L., Kohl A., Bente D.A., Fazakerley J.K., 2012. Tick cell lines for study of Crimean-Congo hemorrhagic fever virus and other arboviruses. Vector Borne Zoonotic Dis. 12 (9): 769-781, doi: 10.1089/vbz.2011.0766

Bock R., Jackson L., de Vos A., Jorgensen W., 2004. Babesiosis of cattle. Parasitol. 129 (S1): S247-269, doi: 10.1017/s0031182004005190

Camicas J.L., Robin Y., Le Gonidec G., Saluzzo J.F., Jouan A., Cornet J.P., Chauvancy G., Ba K., 1986. Etude écologique et nosologique des arbovirus transmis par les tiques au Sénégal. 3. Les vecteurs potentiels du virus de la fièvre hémorragique de Crimée-Congo (virus CCHF) au Sénégal et en Mauritanie. Cah. Orstom., Sér. Ent. Med. Parasitol. 24 (4): 255-264

Camicas J.L., Wilson M.L., Cornet J.P., Digoutte, J.P., Calvo M.A., Adam F., Gonzalez J.P., 1990. Ecology of Ticks as potential vectors of Crimean-Congo haemorrhagic fever virus in Senegal: epidemiological implications. Arch. Virol. [Suppl. 1]: 303-322, doi: 10.1007/978-3-7091-9091-3_34

Camicas J.L., Cornet J.P., Gonzalez J.P., Wilson M.L., Adam F., Zeller H., 1994. La fièvre hémorragique de Crimée-Congo au Sénégal. Dernières données sur l'écologie du virus CCHF. Bull. Soc. Path. Exot. 87: 11-16

Camicas J.L., Hervy J.P., Adam F., Morel P.C., 1998. Les tiques du monde. Nomenclature, stades décrits, hôtes, répartition. Orstom, Paris, France, $240 \mathrm{p}$.

Cohen N.D., Carter C.N., Thomas Jr M.A., Angulo A.B., Eugster A.K., 1990. Clinical and epizootiologic characteristics of dogs seropositive for Borrelia burgdorferi in Texas: 110 cases (1988). J. Am. Vet. Med. Assoc., 197 (7): 893-898

CRORA, 1998. Rapport annuel, Institut Pasteur, Dakar, Sénégal, 141 p.

De Waal D.T., Potgieter F.T., Bigalke R.D. 1987. The transstadial transmission of Babesia caballi by Rhipicephalus evertsi evertsi. Onderstepoort J. Vet. Res. 54: 655-656

Degallier N., Cornet J.P., Saluzzo J.F., Germain M., Hervé J.P., Camicas J.L. Sureau P., 1985. Ecologie des arbovirus à tiques en République Centrafricaine. Bull. Soc. Path. Exot. 78 (3): 296-310

Del Hoyo J., Elliott A., Sargatal J., 1994. Handbook of the birds of the world, Vol 2: New world Vultures to Guineafowls. Lynx, Barcelona, Spain, 638 p.

Ehounoud C.B., Yao K.P., Dahmani M., Achi Y.L., Amanzougaghene N., Kacou N'Douba A., N'Guessan J.D., et al., 2016. Multiple pathogens including potential new species in tick vectors in Côte d'Ivoire. PLOS Negl. Trop. Dis. 10 (2): e0004455, doi: 10.1371/journal.pntd.0004455

Fourie J.J., Stanneck D., Luus H.G., Beugnet F., Wijnveld M., Jongejan F. 2013. Transmission of Ehrlichia canis by Rhipicephalus sanguineus ticks feeding on dogs and on artificial membranes. Vet. Parasitol., 197 (3-4): 595-603, doi: 10.1016/j.vetpar.2013.07.026

Grard G., Lemasson J.J., Sylla M., Dubot A., Cook S., Molez J.F., Pourrut X., et al., 2006. Ngoye virus: a novel evolutionary lineage within the genus Flavivirus. J. Gen. Virol., 87 (11): 3273-3277, doi: 10.1099/vir.0.82071-0

Gueye A., Mbengue M., Douf A., Seye M., 1986. Ticks and haemoparasites of livestock in Senegal. Rev. Elev. Med. Vet. Pays Trop., 39 (3-4): 381-393, doi: 10.19182/remvt.8568

Guglielmone A.A., Robbins R.G., Apanaskevich D.A., Petney T.N., Estrada-Peña A., Horak I.G., Shao R., et al., 2010. The Argasidae, Ixodidae and Nuttalliellidae (Acari: Ixodidae) of the world: a list of valid species names. Zootaxa. 2528: 1-28, doi: 10.11646/zootaxa.2528.1.1

Haig D.A., Woodall J.P., Danskin D., 1965. Thogoto Virus: a hitherto undescribed agent isolated from ticks in Kenya. J. Gen. Microbiol., 38 (3): 389 394, doi: 10.1099/00221287-38-3-389

Hekimoğlu O, Sağlam İ, Özer N, Estrada-Peña A., 2016. New molecular data shed light on the global phylogeny and species limits of the Rhipicephalus sanguineus complex. Ticks Tick Borne Dis., 7 (5): 798-807, doi: 10.1016/j. ttbdis.2016.03.014

Kasei R., Diekkrüger B., Leemhuis C., 2010. Drought frequency in the Volta Basin of West Africa, Sustain. Sci. 5: 89, doi:10.1007/s11625-009-0101-5
Kocan K.M., de la Fuente J., Blouin E.F., Coetzee J.F., Ewing S.A., 2010. The natural history of Anaplasma marginale. Vet. Parasitol., 167 (2-4): 95-107, doi: 10.1016/j.vetpar.2009.09.012

Kovats R.S., Campbell-Lendrum D.H., McMichel A.J., Woodward A., Cox J.St.H., 2001. Early effects of climate change: do they include changes in vector-borne disease? Phil. Trans. R. Soc. B, 356: 1057-1068, doi: 10.1098/ rstb.2001.0894

Le Barbé L., Lebel T., Tapsoba D., 2002. Rainfall variability in West Africa during the years 1950-1990. J. Climate. 15 (2): 187-202, doi: 10.1175/1520-0442(2002)015<0187:RVIWAD>2.0.CO;2

Le Gonidec G., 1975. Activités du laboratoire des arbovirus. In : Rapport sur le fonctionnement technique de I'Institut Pasteur de Dakar. Années 1971-19721973. Institut Pasteur, Dakar, Sénégal, 54-64

Lee V.H., Kemp G.E., Madbouly M.H., Moore D.L., Causey O.R., Casals J., 1974. Jos, a new tick-borne virus from Nigeria. Am. J. Vet. Res. 35 (9): 11651167

L'Hôte Y, Mahé G., 1996. Afrique de l'Ouest et centrale. Précipitations moyennes annuelles (période 1951-1989). Carte du déplacement vers le sud des isohyètes. Orstom, Paris, France

Main A.J., Kloter K.O, Camicas J.L., Robin Y., Sarr M., 1980. Wad Medani and Soldado viruses from ticks (Ixodoidea) in West Africa. J. Med. Entomol., 17 (4): 380-382, doi: 10.1093/jmedent/17.4.380

Matthysse J.G., Colbo M.H., 1987. The Ixodid ticks of Uganda, together with species pertinent to Uganda because of their present known distribution. Entomological Society of America, College Park, MD, USA, 426 p.

Mediannikov O., Fenollar F., Socolovschi C., Diatta G., Bassene H., Molez J.F., Sokhna C., et al., 2010. Coxiella burnetii in humans and ticks in rural Senegal. PLoS Negl. Trop. Dis. 4 (4): e654. doi: 10.1371/journal.pntd.0000654

Morel P.C., 1956. Le Parc national du Niokolo-Koba (Premier fascicule). XV. Tiques d'animaux sauvages. Mém. Inst. Fr. Afr. Noire, 48 : 229-232

Morel P.C., 1957. Rhipicephalus boueti n. sp. (Acarina, Ixodidae), parasite des damans du Dahomey. Bull. Soc. Path. Exot. 50 (5): 696-700

Morel P.C., 1958. The ticks in domestic animals in French West Africa. Rev. Elev. Med. Vet. Pays Trop., 11 (2): 153-189, doi: 10.19182/remvt.7033

Morel P.C., 2003. Les tiques d'Afrique et du Bassin méditerranéen. Contribution à la connaissance de la distribution des tiques en Éthiopie continentale (388 p.) + Annexe cartographique de 62 cartes. CD-Rom, Cirad, Montpellier, France

Morel P.C., Vassiliades, G., 1962. The Rhipicephalus of the group sanguineus (Acari: Ixodoidea). Rev. Elev. Med. Vet. Pays Trop., 15 (4): 343-386, doi: 10.19182/remvt.7132

Morel P.C., Vassiliades, G., 1964. West African Rhipicephalus muhsamae n. sp. description (Rh. Simus group; Acari: Ixodoidea). Rev. Elev. Med. Vet. Pays Trop., 17 (4): 619-636, doi: 10.19182/remvt.7304

Murrell A., Barker S.C., 2003. Synonymy of Boophilus Curtice, 1891 with Rhipicephalus Koch, 1844 (Acari: Ixodidae). Syst. Parasitol. 56: 169-172, doi: 10.1023/B:SYPA.0000003802.36517.a0

Nava S., Estrada-Peña A., Petney T., Beati L., Labruna M.B., Szabó M.P.J., Venzal J.M., et al., 2015. The taxonomic status of Rhipicephalus sanguineus (Latreille, 1806). Vet. Parasitol. 208 (1-2): 2-8. doi: 10.1016/j.vetpar.2014.12.021

NOAA, 2017. Global climate report. NCEI, Asheville, NC, USA

Nowak R.M., 1999. Walker's Mammals of the World (6th Edn.), 2 vol. Johns Hopkins University Press, Baltimore, MD, USA 1936 p.

Parola P., Raoult D., 2001. Ticks and tick-borne bacterial diseases in humans: an emerging infectious threat. Clin. Infect. Dis., 32 (6): 897-928 (erratum, 33: 749), doi: 10.1086/319347

Parola P., Paddock C.D., Raoult D., 2005. Tick-borne rickettsioses around the world: emerging diseases challenging old concepts. Clin. Microbiol. Rev. 18 (4): 719-756, doi: 10.1128/CMR.18.4.719-756.2005

Patz J.A., Olson S.H., Uejio C.K., Gibbs H.K., 2008. Disease emergence from global climate and land use change. Med. Clin. North Am. 92 (6): 14731491, doi: 10.1016/j.mcna.2008.07.007

Pegram R.G., Clifford C.M., Walker J.B., Keirans J.E., 1987. Clarification of the Rhipicephalus sanguineus group (Acari, Ixodoidea, Ixodidae). I. R. sulcatus Neumann, 1908 and R. turanicus Pomerantsev, 1936. Syst. Parasitol., 10 (1): 3-26, doi: 10.1007/BF00009099

Potgieter F.T., 1979. Epizootiology and control of anaplasmosis in South Africa. J. South Afr. Vet. Assoc. 50 (4): 367-372

Reye A.L., Arinola O.G., Hübschen J.M., Mullera C.P., 2012. Pathogen prevalence in ticks collected from the vegetation and livestock in Nigeria. Appl. Environ. Microbiol., 78 (8): 2562-2568, doi: 10.1128/AEM.06686-11 
Robin Y., Camicas J.L., Jan C., Heme G., Cornet M., Valade M., 1978. Ecology of tick arboviruses in arid areas of Senegal. In: Transcontinental connections of migrating birds and their role in distribution of Arboviruses. Papers of the Symposium 1976, Novosibirsk (Akademgorodok) (Ed. Cherepanov A.I.). Nauka, Novosibirsk, Russia, 209-211

Serdeczny O., Adams S., Baarsch F., Coumou D., Robinson A., Hare W., Schaeffer M., et al., 2016. Climate change impacts in sub-Saharan Africa: from physical changes to their social repercussions. Reg. Environ. Change, 17: 1585-1600, doi: 10.1007/s10113-015-0910-2

Shanahan T.M., Overpeck J.T., Anchukaitis K.J., Beck J.W., Cole J.E., Dettman D.L., Peck J.A., et al., 2009. Atlantic forcing of persistent drought in West Africa. Science, 324: 377-380, doi: 10.1126/science.1166352

Sonenshine D.E., 1992. Biology of ticks, Vol. 2. Oxford University Press, NY, USA, $465 \mathrm{p}$.

Sureau P., Cornet J.P., Germain M., Camicas J.L., Robin Y., 1976. Enquête sur les arbovirus transmis par les tiques en République Centrafricaine (19731974). Isolement des virus Dugbe, CHF/Congo, Jos et Bhanja. Bull. Soc. Path. Exot. 69 (1): 28-33

Sylla M., Molez J.F., Cornet J.P., Mondet B., Camicas J.L., 2007. Les tiques (Acari: Ixodida) du Sénégal : fréquence des hôtes répertoriés, dynamique saisonnière et chorologie d'Amblyomma (Xiphiastor) variegatum (Fabricius, 1794). Acarologia, 47 (1-2): 13-23

Sylla M., Molez J.F., Cornet J.P., Camicas J.L., 2008a. Impact du changement climatique sur la répartition des tiques au Sénégal et en Mauritanie. Acarologia. 48 (3-4): 137-153

Sylla M., Molez J.F., Cornet J.P, Camicas J.L, Pourrut X., 2008b. Variabilité climatique et répartition de la fièvre hémorragique de Crimée-Congo et de la cowdriose, maladies à tiques au Sénégal. Acarologia, 48 (3-4): 155-161
Tomassone L., Camicas J.L., Pagani P., Diallo O.T., Mannelli A., De Meneghi D., 2004. Monthly dynamics of ticks (Acari: Ixodida) infesting N'Dama cattle in the Republic of Guinea. Exp. Appl. Acarol. 32 (3): 209-218, doi: 10.1023/B:APPA.0000021771.34520.ab

Villiers A., 1955. Note sur quelques Ixodidae et Gamasidae parasites des vertébrés rencontrés en Afrique occidentale française. Bull. Inst. Fr. Afr. Noire. 174 (2): 444-454

Vinograd I.A., Krasovskaia I.A., Sidorova G.A., Sazonov A.A., Bosh R., 1975. Isolation of Bhanja arbovirus from Boophilus decoloratus ticks in Cameroon. Voprosy Virusol., 1: 63-67

Walker J.B., Keirans J.E., Horak I.G., 2000. The genus Rhipicephalus (Acari, Ixodidae). A guide to the brown ticks of the world. Cambridge University Press, Cambridge, UK, 643 p., doi: 10.1017/CBO9780511661754

Williams R.W., Causey O.R., Kemp G.E., 1972. Ixodid ticks from domestic livestock in Ibadan, Nigeria as carriers of viral agents. J. Med. Entomol. 9 (5): 443-445, doi: 10.1093/jmedent/9.5.443

Wilson M.L. Gonzalez J.P., LeGuenno B., Cornet J.P., Guillaud M., Calvo M.A., Digoutte J.P., et al., 1990. Epidemiology of Crimean-Congo haemorrhagic fever in Senegal: temporal and spatial patterns. Arch. Virol. [Suppl. 1]: 323 340, doi: 10.1007/978-3-7091-9091-3_35

Wilson D.E., Reeder D.M., 1992. Mammal species of the world. A taxonomic and geographic reference. Second edition. Smithsonian Institution Press, Washington, DC, USA, $1206 \mathrm{p}$.

Zhou Y., Zhang H., Cao J., Gong H., Zhou J., 2016. Epidemiology of toxoplasmosis: role of the tick Haemaphysalis longicornis. Infect. Dis. Pov. 5: 14, doi: 10.1186/s40249-016-0106-0

\section{Résumé}

Sylla M., Souris M., Gonzalez J.-P. Tiques du genre Rhipicephalus Koch, 1844 au Sénégal : synthèse hôtes associés, chorologie, et agents pathogènes transmis aux humains et aux animaux

Les tiques du genre Rhipicephalus (Acari : Ixodidae) connues au Sénégal ont été passées en revue. Les données présentées proviennent d'une collection de tiques conservée au Laboratoire d'entomologie médicale de l'IRD depuis 1967 et continuellement enrichie d'échantillons prélevés sur différents hôtes vertébrés capturés au cours de divers projets conduits au Sénégal de 1987 à 2007. Quinze espèces de Rhipicephalus, provenant de 1127 collectes référencées, ont été caractérisées. Parmi elles, se trouvaient trois espèces du sous-genre Boophilus : Rhipicephalus (Bo.) annulatus, Rh. (Bo.) decoloratus et Rh. (Bo.) geigyi. Les douze autres espèces étaient $R h$. boueti, Rh. cuspidatus, $R h$. evertsi, Rh. guilhoni, Rh. lunulatus, Rh. muhsamae, Rh. sanguineus, Rh. senegalensis, Rh. sulcatus, Rh. tricuspis, Rh. turanicus et $R h$. ziemanni. De récentes études ont conclu que $R h$. turanicus devrait être considéré comme faisant partie du complexe $R h$. sanguineus s.I. Les données concernant ces deux tiques ont cependant été présentées séparément. Au total, 14165 spécimens de tiques à différents stades de développement ont été échantillonnés. Les données concernant les préférences d'hôtes des différentes espèces, ainsi que leur distribution et leur dynamique saisonnière ont été précisées. Les hôtes vertébrés ont été identifiés et listés dans les différentes zones écologiques du Sénégal. Le rôle vecteur de pathogènes des tiques est passé en revue. Les changements climatiques en cours, entraînant des variations de température et de précipitations, affecteront la distribution et la dynamique des tiques. Cela justifie qu'un tel inventaire soit réalisé, permettant une surveillance précise des risques dus aux maladies (ré)émergentes à tiques.

Mots-clés : Rhipicephalus, hôte, vecteur de maladie, agent pathogène, distribution géographique, environnement, Sénégal

\section{Resumen}

Sylla M., Souris M., Gonzalez J.-P. Garrapatas del género Rhipicephalus Koch, 1844 en Senegal: revisión, asociaciones de huéspedes, cronología y patógenos humanos y animales asociados

Se revisaron las garrapatas del género Rhipicephalus (Acari: Ixodidae) en Senegal. Los datos presentados se originan de una colección de garrapatas mantenida en el Laboratorio de Entomología Médica del IRD desde 1967 y enriquecida continuamente con muestras obtenidas de diferentes huéspedes vertebrados, capturadas durante varios proyectos Ilevados a cabo en Senegal entre 1987 y 2007. Se recolectaron y caracterizaron quince especies de garrapatas Rhipicephalus, conduciendo a 1127 colecciones de referencia. Tres especies fueron de subgéneros Boophilus: Rhipicephalus (Bo.) annulatus, Rh. (Bo.) decoloratus y Rh. (Bo.) geigyi. Las otras doce fueron Rh. boueti, Rh. cuspidatus, Rh. evertsi, Rh. guilhoni, Rh. lunulatus, Rh. muhsamae, Rh. sanguineus, Rh. senegalensis, Rh. sulcatus, Rh. tricuspis, Rh. turanicus y Rh. ziemanni. A pesar de que hubo indicios recientes de que $R h$. turanicus debería de haber sido considerada como parte del complejo Rh. sanguineus s.l., los datos concernientes a estas dos garrapatas se presentaron separadamente. La colección incluyó 14165 especímenes de garrapatas en diferentes estadios de desarrollo. Se presentan también los datos concernientes a las relaciones con los huéspedes, así como la dinámica de distribución y estacional. Los huéspedes vertebrados fueron identificados y enumerados en las diferentes zonas ecológicas de Senegal. Se revisó el papel de las garrapatas como potenciales vectores de patógenos. Los cambios climáticos, causantes de variaciones en la pluviometría y la temperatura, impactarán la distribución y la dinámica de las garrapatas. La situación indujo la necesidad de este inventario de las poblaciones de garrapatas para la vigilancia y supervisión de enfermedades (re)emergentes transmitidas por garrapatas.

Palabras clave: Rhipicephalus, huéspedes, vectores, organismos patógenos, distribución geográfica, medio ambiente, Senegal 
